\title{
Creep Behavior of 2.25Cr-1Mo Steel Shield Metal Arc Weldment
}

\author{
Shimpei FUJIBAYASHI, Koji KAWANO, Takayuki KOMAMURA ${ }^{11}$ and Takaya SUGIMURA ${ }^{11}$ \\ Engineering Design \& Technical Development, Idemitsu Engineering Co., Ltd., 37-24, Shinden-cho, Chuo-ku, Chiba $260-0027$ \\ Japan. $\quad 1$ ) Engineering \& Maintenance Department, Idemitsu Kosan Co., Ltd., 24-4, Anesaki Kaigan, Ichihara $299-0107$ \\ Japan.
}

(Received on September 18, 2003; accepted in final form on November 5, 2003)

\begin{abstract}
In order to guarantee the safety of high temperature components and prevent unscheduled outage, remnant life assessment for creep is quite important. The experiences in actual components reveal that almost all the problems relating to creep are generated at the weldment, which contains microstructures with different creep properties from those presumed in the parent material. Nowadays, it is generally accepted that a terminal failure mode of low alloy ferritic steels or tempered martensitic steels become Type IV, taking place at the Intercritical HAZ or Fine Grained HAZ. However, in the present work using $2.25 \mathrm{Cr}-1 \mathrm{Mo}$ steel welds fabricated with basic coated Shield Metal Arc Weld (SMAW) consumables, the most prevalent failure mode was Type I in the center of weld metal rather than Type IV. And this tendency was more pronounced at low stresses, suggesting the possibility of Type I cracking in actual components. It was concluded that poor creep strength of $2.25 \mathrm{Cr}-1 \mathrm{Mo}$ weld metal was ascribed to its fully bainitic microstructure in which carbides evolution was accelerated and $\mathrm{M}_{2} \mathrm{C}$ depletion took place earlier than base metal.
\end{abstract}

KEY WORDS: creep; weldment; $2.25 \mathrm{Cr}-1$ Mo steel; weld metal; bainite.

\section{Introduction}

Nowadays, most refiners are trying to extend the interval of turnarounds in order to increase the competitiveness of their plants. Therefore, more accurate life assessment techniques based upon profound knowledge on the material's reaction to an operational environment are required to guarantee the soundness of a component. It is pretty much so for old high temperature components whose operating duration exceed their design life of $100000 \mathrm{~h}$. In the case of high temperature refining components, the life determining damage mechanism will be creep when so called dry corrosion such as sulfidation, High Temperature Hydrogen Attack (HTHA), metal dusting and so on are prevented by careful design, operation and maintenance. One of the problems in assessing component's integrity against creep is that this phenomenon is not necessarily associated with apparent symptoms such as reduction in wall thickness or surface cracking until the final stage of catastrophic failure. The presence of weldment, which is inevitable for most components operated in actual plants, makes the remnant life assessment more difficult to perform. However, it is the weldment where the ultimate creep failure often takes place like other mechanical problems. The weldment is composed of parent material, weld metal and Heat Affected Zone (HAZ) produced by heat input during welding. Creep properties of weld metal and HAZ could be significantly different from those of parent material. Shuller et al. ${ }^{1)}$ categorized the creep damage found in the weldment of low alloy ferritic steels into four types based upon the location failed. The failure at parent material is not involved in this classifi- cation since it is quite unlikely. Among them, Type IV cracking at the Intercritical HAZ (ICZ) or Fine Grained HAZ (FGZ) has been considered the most likely terminal failure mode. ${ }^{2)}$

However, in the present work on creep behavior of $2.25 \mathrm{Cr}-1 \mathrm{Mo}$ steel welds, Type I failure in the center of weld metal fabricated with a Shield Metal Arc Weld (SMAW) technique was more prevalent than Type IV. And the transition of failure mode from Type IV to Type I was observed with decrease in testing stresses, suggesting the possibility of Type I failure in actual components. In the followings, features of damage and creep properties of $2.25 \mathrm{Cr}-1 \mathrm{Mo}$ steel weldment shall be discussed.

\section{Experimental Details}

\subsection{Materials}

Two types of parent materials, a commercial plate and specially produced one doped with $\mathrm{P}, \mathrm{Sn}, \mathrm{As}$ and $\mathrm{Sb}$ were prepared. Chemical compositions of parent materials and weld metal are shown in Table 1. $J$ factor and X-bar, which have been utilized to assess the susceptibility to temper embrittlement caused by enrichment of impurities, are also shown. Oxygen content in weld metal, which represents concentration of oxide inclusions, lies in the expected level when basic coated Shield Metal Arc Welding (SMAW) electrodes are employed. ${ }^{3)}$

The same heat treatment prior to welding was given to both plates. Normalizing was performed at $900^{\circ} \mathrm{C}$ for 34 min and then tempering at $730^{\circ} \mathrm{C}$ for $53 \mathrm{~min}$ was given. Microstructure of commercial and high residual parent is 
Table 1. Chemical compositions of parent materials and weld metal (wt \%)

\begin{tabular}{l|c|c|c}
\hline & Commercial cast & High residual cast & Weld metal \\
\hline $\mathrm{C}$ & 0.15 & 0.11 & 0.12 \\
\hline $\mathrm{Si}$ & 0.17 & 0.30 & 0.46 \\
\hline $\mathrm{Mn}$ & 0.58 & 0.52 & 0.78 \\
\hline $\mathrm{P}$ & 0.011 & 0.03 & 0.008 \\
\hline $\mathrm{S}$ & 0.003 & 0.03 & 0.003 \\
\hline $\mathrm{Cr}$ & 2.35 & 2.28 & 2.25 \\
\hline $\mathrm{Mo}$ & 1.01 & 1.01 & 0.99 \\
\hline $\mathrm{Cu}$ & 0.02 & 0.21 & 0.03 \\
\hline $\mathrm{As}$ & 0.001 & 0.021 & 0.0034 \\
\hline $\mathrm{Sn}$ & 0.0004 & 0.039 & 0.0033 \\
\hline $\mathrm{Sb}$ & 0.0004 & 0.054 & 0.0004 \\
\hline $\mathrm{O}$ & 0.0028 & 0.0016 & 0.0247 \\
\hline$J$ factor ${ }^{* 1)}$ & 85.5 & 566 & 140 \\
\hline $\mathrm{X}$-bar ${ }^{* 2}$ & 11.5 & 74.7 & 9.86 \\
\hline *1) $J=(\mathrm{Si}+\mathrm{Mn})(\mathrm{P}+\mathrm{Sn}) \times 10^{4}$ (in wt\%) \\
*2) X-bar $=(10 \mathrm{P}+5 \mathrm{Sb}+4 \mathrm{Sn}+\mathrm{As}) / 100($ in ppm)
\end{tabular}

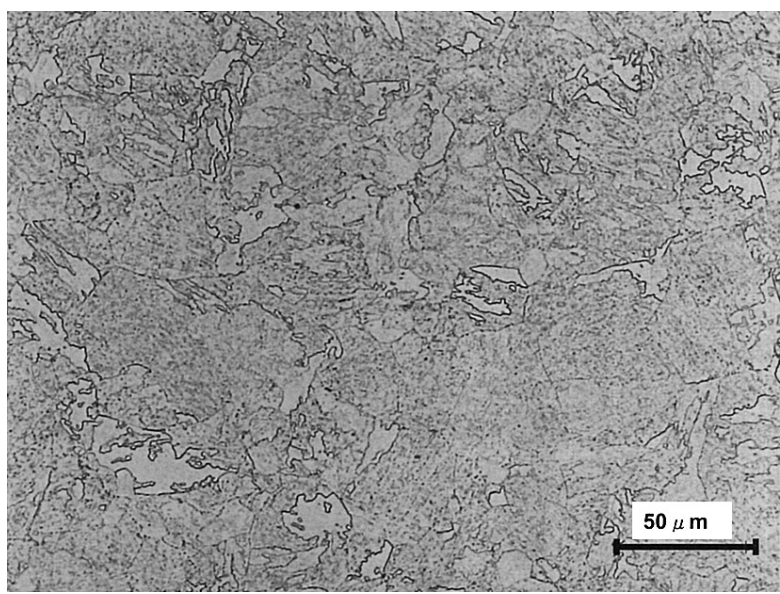

Fig. 1. Optical microstructure of commercial parent.

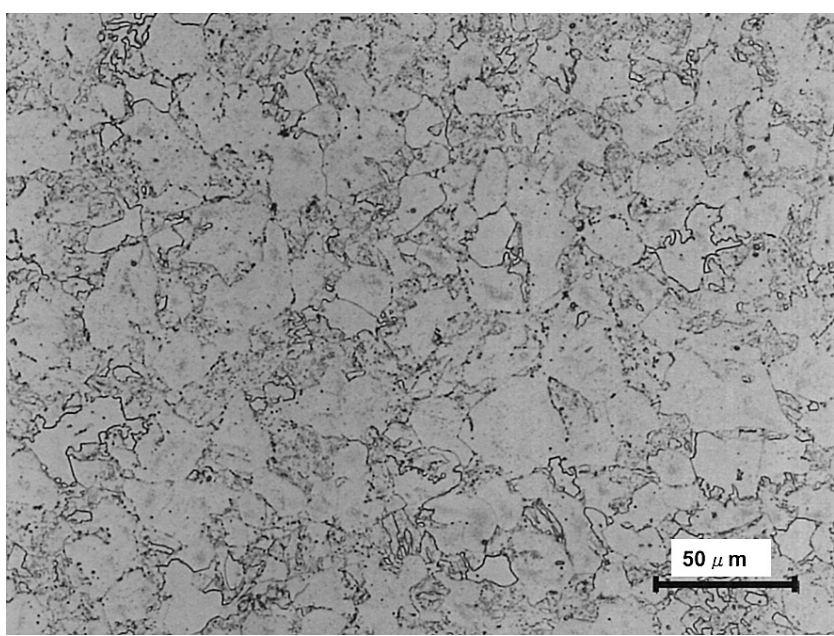

Fig. 2. Optical microstructure of high residual parent.

shown in Figs. 1 and 2, respectively. Parent material of a commercial cast is mainly composed of bainite associated with a small amount of proeutetoid ferrite around Prior Austenite Grain boundary (PAGB). As shown in Fig. 2, a volume fraction of ferrite in a high residual cast is significantly higher compared with a commercial cast.

\subsection{Welding Procedure and Hardness Distribution}

To prepare cross-weld specimens, commercial SMAW
Table 2. Welding condition.

\begin{tabular}{c|c}
\hline Weld preparation & $50^{0} \mathrm{~V}$ with back chipping \\
\hline Number of pass & 23 \\
\hline Electrode diameter $(\mathrm{mm})$ & 5 \\
\hline Welding current $(\mathrm{A})$ & $220 / 260$ \\
\hline Voltage $(\mathrm{V})$ & $20 / 28$ \\
\hline Travel speed $(\mathrm{mm} / \mathrm{min})$ & $120 / 260$ \\
\hline Preheating temperature $\left({ }^{0} \mathrm{C}\right)$ & $150 / 250$ \\
\hline Interpass temperature $\left({ }^{\circ} \mathrm{C}\right)$ & $150 / 250$ \\
\hline PWHT $\left({ }^{\circ} \mathrm{C}\right)$ & $690 \pm 15 \times 8 \mathrm{hrs}$ \\
\hline
\end{tabular}

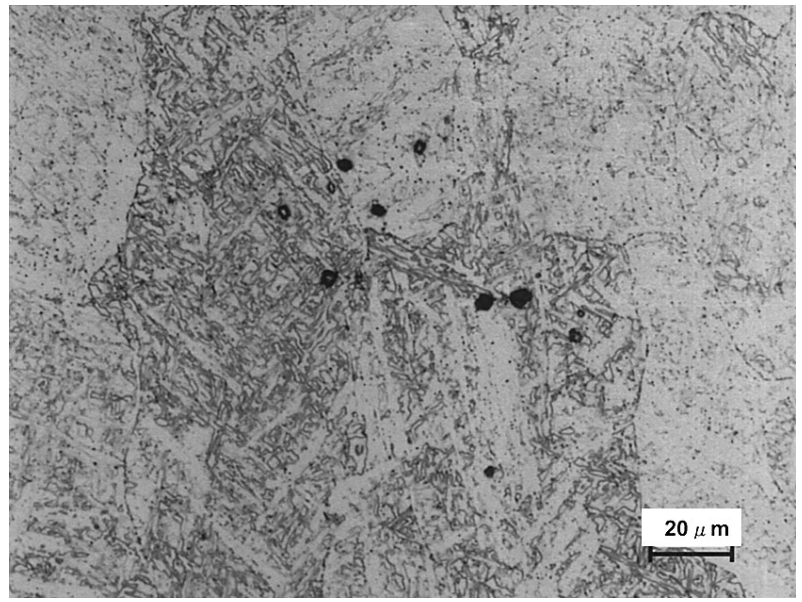

Fig. 3. Optical microstructure of weld metal.

consumables, which were equivalent to AWS E9016B, were applied. Conditions for multi-pass welding for both plates with $32 \mathrm{~mm}$ thickness are shown in Table 2. Microstructure observed in the center of weld metal is predominantly bainitic as shown in Fig. 3. Randomly distributed black dots in this figure are non-metallic inclusions. They tended to be concentrated in the central part of weld deposits. No apparent cusp-like feature of a weld deposit existed in gauge length of creep and tensile specimens. Hardness distribution of commercial/high residual welds measured after PWHT is shown in Fig. 4. The highest hardness is observed at weld metal, ranging from $\mathrm{Hv} 187$ to $\mathrm{Hv} 204$. The averaged hardness of commercial parent, 185, is about Hv 20 higher than that of high residual parent. The ICZs of both materials show slightly lower values compared with parent materials.

\subsection{Specimens and Testing}

Combinations of constituting the weldment were threefold, namely, commercial/commercial, high residual/high residual and commercial/high residual. In the creep tests for welds, a cylindrical standardized specimen with a $10 \mathrm{~mm}$ diameter and $12 \times 12 \mathrm{~mm}^{2}$ square specimen with $90 \mathrm{~mm}$ of gauge length were employed. Creep properties of parent materials were examined by the former type. An area ratio of weld metal in gauge length was approximately $30 \%$ for a cylindrical specimen and $17 \%$ for a square specimen respectively. The surface of a square cross-weld specimen was examined at interruptions during creep tests using a replication technique. All the creep tests were conducted in air with constant load. Grain boundary damage was observed by optical microscopy and Scanning Electron Microscopy (SEM). To analyze the precipitates, carbides and non-metallic inclusions, Transmission Electron 


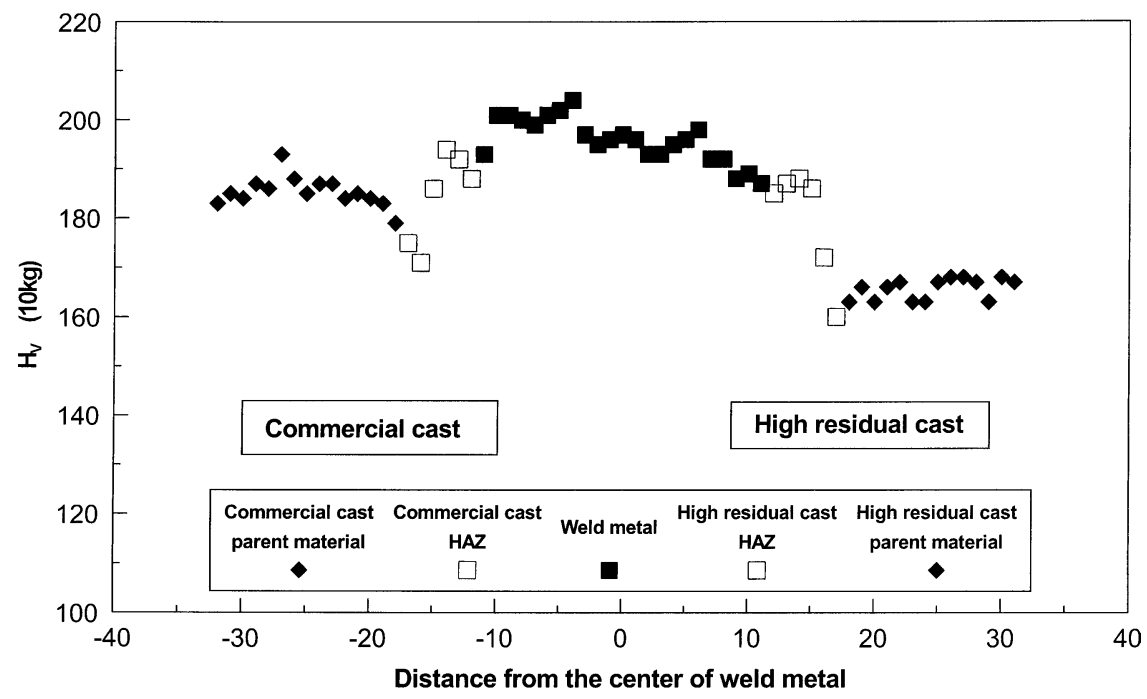

Fig. 4. Hardness distribution of the weldment.

Table 3. Tensile properties of parent materials and welds.

\begin{tabular}{l|c|c|c|c|c|c}
\hline \multicolumn{1}{c|}{ Specimen type } & $\begin{array}{c}\text { Temp. } \\
\left({ }^{0} \mathrm{C}\right)\end{array}$ & $\begin{array}{l}\text { Yield } \\
\text { stress } \\
(\mathrm{MPa})\end{array}$ & $\begin{array}{l}\text { Tensile } \\
\text { strength } \\
(\mathrm{MPa})\end{array}$ & $\begin{array}{l}\text { El. } \\
(\%)\end{array}$ & $\begin{array}{l}\text { RA } \\
(\%)\end{array}$ & $\begin{array}{c}\text { Failure } \\
\text { position }\end{array}$ \\
\hline Commercial cast base metal & RT & 514 & 664 & 29.0 & 78.1 & - \\
\hline Commercial cast base metal & 550 & 394 & 467 & 22.4 & 85.9 & - \\
\hline Commercial/commercial welds & RT & 461 & 617 & 24.4 & 74.2 & Base metal \\
\hline Commercial/commercial welds & 550 & 334 & 395 & 24.2 & 85.2 & Base metal \\
\hline High residual cast base metal & RT & 343 & 550 & 31.4 & 71.3 & - \\
\hline High residual cast base metal & 550 & 247 & 393 & 25.3 & 75.0 & - \\
\hline High residual/high residual welds & RT & 330 & 544 & 20.3 & 62.6 & Base metal \\
\hline High residual/high residual welds & 550 & 223 & 348 & 19.7 & 68.6 & Base metal \\
\hline
\end{tabular}

Microscopy (TEM) and Energy Dispersive X-ray spectroscopy (EDX) were utilized in the observation of carbon extraction replicas and sectioned specimens.

\section{Results}

\subsection{Tensile Properties}

Tensile properties of parent materials and cross-weld specimens at room temperature and $550^{\circ} \mathrm{C}$ are shown in Table 3. Both $0.2 \%$ proof strength and ultimate tensile strength of a commercial cast are higher than those of a high residual cast. In the tensile tests for cross-weld specimens, all the failures took place at the high residual parent material in a ductile transgranular manner.

\subsection{Creep Rupture Properties}

Testing results obtained by cylindrical specimens and square specimens are shown in Tables 4 and 5, respectively. Time to rupture for parent materials and cross-weld specimens is plotted using Larson-Miller Parameter (LMP) in Fig. 5. In the present work, the constant $C$ has been assumed to be 20 . No remarkable difference in rupture life between a cylindrical and square cross-weld specimen can be found. For the reference, the mean rupture strength and lower boundary derived from the NIMS data base ${ }^{4)}$ for normalized and tempered 2.25Cr-1Mo plates are also shown. To derive theses averaged and minimum values, the second power polynomial equations were employed. The curve for lower boundary strength was obtained by correlating TimeTemperature parameters with stresses that were $20 \%$ lower than those in testing.

The parent material of a commercial cast showed higher creep strength than the average. On the other hand, the creep strength for parent material containing higher tramp elements, which failed transgrnularly, was lower than the mean values. Higher creep strength of a commercial cast is consistent with tensile properties at room temperature and $550^{\circ} \mathrm{C}$. However, in spite of higher strength in tensile tests, the most predominant failure mode for cross-weld specimens was Type I taking place in the center of weld metal. Twenty-four out of thirty-three cross-weld specimens failed in this mode. Another failure mode was Type IV at the outer-edge of HAZ on the side of a high residual cast. No parent material failure has taken place. Creep curves tested at $600^{\circ} \mathrm{C}$ and $100 \mathrm{MPa}$ using cylindrical specimens for commercial parent, high residual parent, commercial/commercial welds and high residual/high residual welds are shown in Fig. 6. Due to the presence of weld metal, higher strain of weldment, especially in a commercial/commercial weldment failed in a Type I manner, is observable. The measured minimum creep rate of the commercial/commercial weldment became approximately four times higher than that of a commercial parent. A high residual/high residual weldment revealing slightly accelerated deformation failed in a Type IV manner. Considering the area ratio of weld metal $(30 \%)$, it can be considered that the minimum creep rate of weld metal is an order of magnitude higher than that of a commercial parent. It has been demonstrated by the Finite Element Analysis (FEA) that the soft weld with lower creep strength than base metal can cause strain accel- 
ISIJ International, Vol. 44 (2004), No. 3

Table 4. Creep test results for cylindrical specimens.

\begin{tabular}{|c|c|c|c|c|c|c|c|}
\hline Specimen ID & $\begin{array}{r}\text { Temp } \\
\left({ }^{0} \mathrm{C}\right)\end{array}$ & $\begin{array}{l}\text { Stress } \\
(\mathrm{MPa})\end{array}$ & $\begin{array}{l}t_{r} \\
(\mathrm{~h})\end{array}$ & $\begin{array}{l}\text { El. } \\
(\%)\end{array}$ & $\begin{array}{l}\text { R.A. } \\
(\%)\end{array}$ & $\begin{array}{l}\text { LMP at failure }{ }^{* 1)} \\
\left(\mathrm{x} 10^{3}\right)\end{array}$ & $\begin{array}{l}\text { Failure } \\
\text { mode }\end{array}$ \\
\hline $\mathrm{CBM1}^{* 21}$ & 600 & 100 & 1,685 & 42 & 91 & 20.28 & - \\
\hline CBM2 & 625 & 80 & 823 & 53 & 81 & 20.58 & - \\
\hline CBM3 & 650 & 50 & 1,788 & 42 & 95 & 21.46 & - \\
\hline CBM4 & 650 & 60 & 752 & 55 & 95 & 21.11 & - \\
\hline CBM5 & 680 & 40 & 607 & 56 & 95 & 21.71 & - \\
\hline HRBM1 $^{* 2)}$ & 600 & 100 & 424 & 33 & 85 & 19.75 & - \\
\hline HRBM2 & 625 & 80 & 353 & 40 & 90 & 20.25 & - \\
\hline HRBM3 & 650 & 50 & 767 & 44 & 93 & 21.12 & - \\
\hline HRBM4 & 650 & 60 & 472 & 60 & 92 & 20.93 & - \\
\hline HRBM5 & 680 & 40 & 325 & 99 & 96 & 21.45 & - \\
\hline $\mathrm{C} / \mathrm{CW} 1^{* 2)}$ & 600 & 100 & 490 & 23 & 89 & 19.81 & Type I \\
\hline $\mathrm{C} / \mathrm{CW} 2$ & 625 & 80 & 292 & 26 & 92 & 20.17 & Type I \\
\hline $\mathrm{C} / \mathrm{CW} 3$ & 650 & 50 & 436 & 31 & 96 & 20.90 & Type I \\
\hline $\mathrm{C} / \mathrm{HRW1}^{* 2)}$ & 600 & 80 & 946 & 16 & 37 & 20.06 & Type $I^{* 3)}$ \\
\hline C/HRW2 & 600 & 100 & 355 & 19 & 62 & 19.69 & Type $I^{* 31}$ \\
\hline C/HRW3 & 625 & 60 & 910 & 30 & 92 & 20.62 & Type I \\
\hline C/HRW4 & 625 & 80 & 291 & 29 & 66 & 20.17 & Type $I^{*}{ }^{* 3)}$ \\
\hline C/HRW5 & 650 & 50 & 485 & 38 & 95 & 20.94 & Type I \\
\hline HR/HRW1 ${ }^{* 2)}$ & 600 & 80 & 970 & 21 & 46 & 20.07 & Type IV \\
\hline HR/HRW2 & 600 & 100 & 337 & 23 & 56 & 19.67 & Type IV \\
\hline HR/HRW3 & 625 & 60 & 825 & 35 & 92 & 20.58 & Type I \\
\hline HR/HRW4 & 625 & 80 & 238 & 26 & 56 & 20.09 & Type IV \\
\hline HR/HRW5 & 650 & 50 & 419 & 36 & 94 & 20.88 & Type I \\
\hline
\end{tabular}

*1) : The constant $C$ is 20 .

*2): CBM is the base metal of the commercial cast, HRBM is the base metal of the high residual cast, $\mathrm{C} / \mathrm{CW}$ is the commercial / commercial cast welds, C/HRW is the commercial / high residual cast welds and HR/HR is the high residual / high residual cast welds.

*3): Type IV failures took place on the high residual cast side.

Table 5. Creep test results for square cross-weld specimens.

\begin{tabular}{l|c|c|c|c|c|c}
\hline \multicolumn{1}{|c|}{ Specimen ID } & $\begin{array}{l}\text { Temp. } \\
\left({ }^{0} \mathrm{C}\right)\end{array}$ & $\begin{array}{l}\text { Stress } \\
(\mathrm{MPa})\end{array}$ & $\begin{array}{l}t_{r} \\
(\mathrm{~h})\end{array}$ & $\begin{array}{l}\text { El. } \\
(\%)\end{array}$ & $\begin{array}{c}\text { LMP at failure }{ }^{* 1)} \\
\left(\mathrm{x} 10^{3}\right)\end{array}$ & Failure mode \\
\hline SC/CW1 ${ }^{* 2)}$ & 625 & 60 & 814 & 30 & 20.57 & Type I \\
\hline SC/CW2 & 625 & 80 & 281 & 17 & 20.16 & Type I \\
\hline SC/CW3 & 650 & 40 & 802 & 22 & 21.14 & Type I \\
\hline SC/CW4 & 650 & 50 & 332 & 19 & 20.79 & Type I \\
\hline SC/CW5 & 650 & 60 & 249 & 22 & 20.67 & Type I \\
\hline SC/HRW1 ${ }^{* 2)}$ & 600 & 70 & 2,066 & 21 & 20.35 & Type IV ${ }^{* 3)}$ \\
\hline SC/HRW2 & 625 & 50 & 1,778 & 21 & 20.88 & Type I \\
\hline SC/HRW3 & 625 & 60 & 662 & 21 & 20.49 & Type I \\
\hline SC/HRW4 & 625 & 80 & 282 & 23 & 20.16 & Type I \\
\hline SC/HRW5 & 650 & 40 & 826 & 24 & 21.15 & Type I \\
\hline SC/HRW6 & 650 & 50 & 419 & 22 & 20.88 & Type I \\
\hline SC/HRW7 & 650 & 60 & 264 & 28 & 20.70 & Type I \\
\hline SHR/HRW1 ${ }^{* 2}$ & 575 & 100 & 1,671 & 14 & 19.69 & Type IV \\
\hline SHR/HRW2 & 590 & 80 & 1,578 & 16 & 20.02 & Type IV \\
\hline SHR/HRW3 & 600 & 70 & 1,669 & 26 & 20.27 & Type I \\
\hline SHR/HRW4 & 625 & 60 & 670 & 25 & 20.50 & Type I \\
\hline SHR/HRW5 & 625 & 80 & 306 & 30 & 20.19 & Type I \\
\hline SHR/HRW6 & 650 & 40 & 826 & 24 & 21.15 & Type I \\
\hline SHR/HRW7 & 650 & 50 & 419 & 22 & 20.88 & Type I \\
\hline SHR/HRW8 & 650 & 60 & 264 & 28 & 20.70 & Type I \\
\hline
\end{tabular}

*1) : The constant $C$ is 20 .

*2): $\mathrm{SC} / \mathrm{CW}$ is the square commercial / high residual cast weldment, SC/HRW is the square commercial / high residual cast weldment and SHR/HRW is the square high residual / high residual cast weldment.

*3) : Type IV failure took place on the high residual cast side.

eration at the weld metal/ parent material interface (HAZ). For example, Nicol et al. ${ }^{5)}$ examined the strain rate distribution through the welds using bimaterial model (base metal and weld metal). It was found that the strain rate at the weld $\mathrm{metal} /$ parent interface increased with the creep mismatch in the case of a soft weld. In the current work, however, creep damage at the HAZ has been found only on the high residual side showing lesser difference in strain rate. This result suggests that the susceptibility to Type IV damage owned by each ICZ would be more important than additional stress associated with the creep mismatch.

As shown in Fig. 5, time to Type IV failure lies above the lower boundary of base metal. On the other hand, the values of $L M P$ associated with weld metal failure become smaller than the lower boundary for base metal at low stresses. The transition of failure mode, from Type IV to Type I with de- 


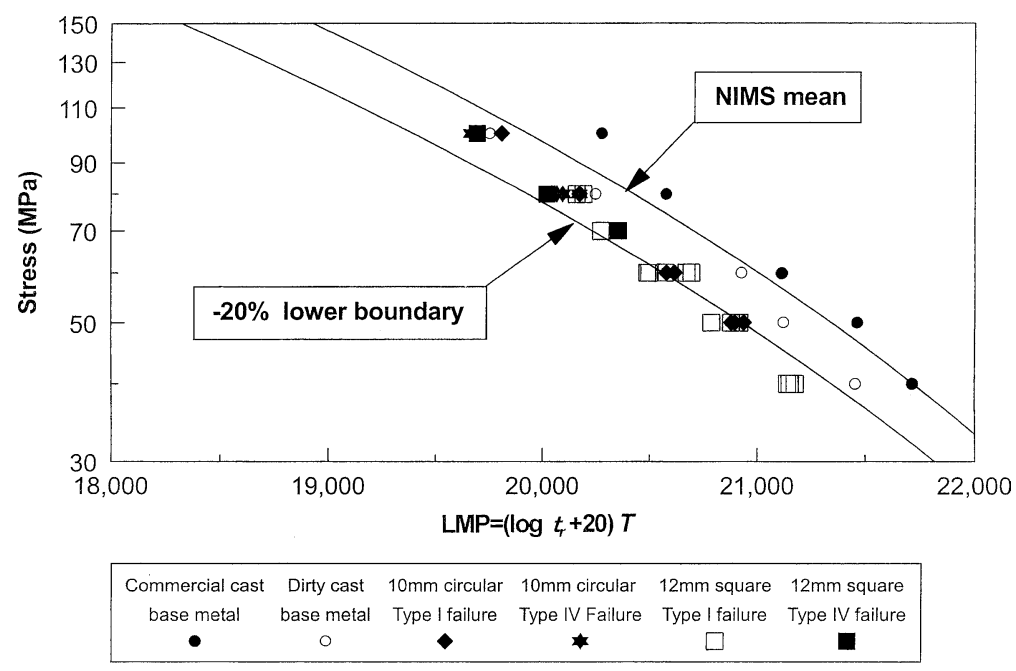

Fig. 5. Larson-Miller Parameter-stress correlation for cylindrical and square specimens.

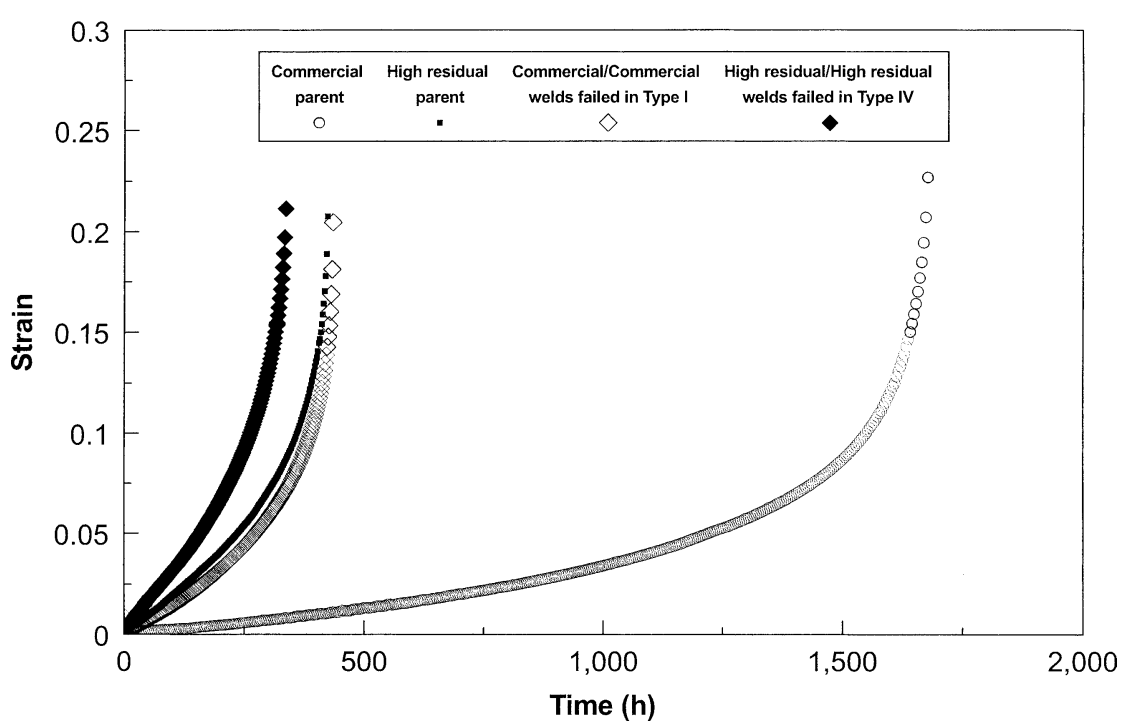

Fig. 6. Creep curves of parent material and cross-weld specimens.

crease in testing stresses, was also observed by Watanabe et $a l .{ }^{6)}$ in the work on the creep behavior of $2.25 \mathrm{Cr}-1 \mathrm{Mo}$ steel weldment, which was prepared by Submerged Arc Welding (SAW). Time to failure for both types of failure in the present work, namely, the ultimate failure at weld metal and that at the ICZ, was well described by the power law relationship given by the following equation.

$$
t_{\mathrm{r}}=A \sigma^{-n} \exp (Q / R T)
$$

or

$$
P=\ln t_{\mathrm{r}}-Q / R T=\ln A-n \ln \sigma
$$

where, $t_{r}$ is the time to failure, $A$ is the constant, $Q$ is the activation energy in $\mathrm{kJ} / \mathrm{mol}, R$ is the universal gas constant and $T$ is the absolute temperature in $\mathrm{K}$.

By the regression analysis, $A, Q$ and $n$ determining the rupture life for each manner were derived. These values for cross-weld specimens failed in a Type I and Type IV manner are tabulated in Table 6. Time to rupture data for both failure modes, nine for Type IV and twenty-four for Type I, are compared with predicted values using Orr-SharbyDorn Parameter in Fig. 7. It was found that rupture life pre-
Table 6. Constants for the power law relationship on rupture life.

\begin{tabular}{l|c|c|c}
\hline Failure Type & $A$ & $n$ & $\begin{array}{c}Q \\
(\mathrm{~kJ} / \mathrm{mol})\end{array}$ \\
\hline $\begin{array}{l}\text { Failure at } \\
\text { weld metal }\end{array}$ & $1.25 \times 10^{-11}$ & 3.39 & 340.7 \\
\hline $\begin{array}{l}\text { Failure at the ICZ } \\
\text { on the high residual cast }\end{array}$ & $3.50 \times 10^{-10}$ & 4.68 & 357.0 \\
\hline
\end{tabular}

diction for both types was achieved with the accuracy of a factor of two. It should be noted that extrapolated life derived by Eq. (1) becomes significantly shorter than that obtained by $L M P$. For example, the predicted time to Type I failure based upon the power law relationship is $170000 \mathrm{~h}$ at $50 \mathrm{MPa}$ and $540^{\circ} \mathrm{C}$, which is the typical superheated steam temperature in conventional oil firing power generating plants. The equivalent value of $L M P$ is $20.51 \times 10^{3}$, which is remarkably smaller than experimental values in the present work, ranging from $20.79 \times 10^{3}$ to $20.94 \times 10^{3}$. Indeed, Henry et $a .^{7)}$ found the systematic decrease in $L M P$ associated with decrease in temperatures at the iso-stress creep rupture tests for $2.25 \mathrm{Cr}-1 \mathrm{Mo}$ steel weld metal. 


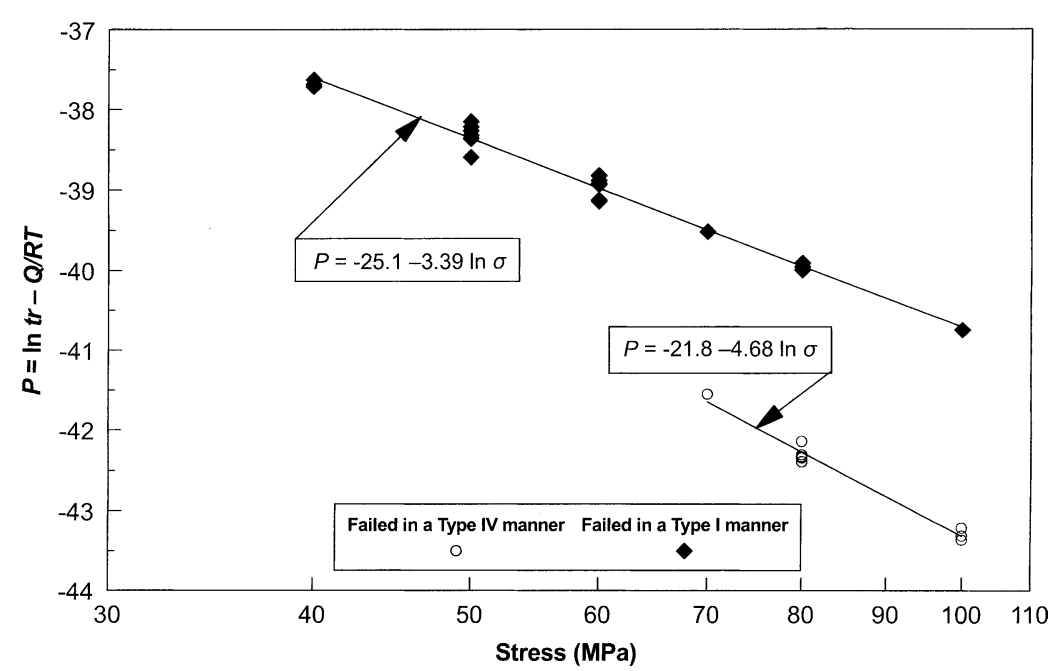

Fig. 7. Relationship between stress and Orr-Sharby-Dorn Parameter for Type IV and Type I failure.

\subsection{Damage Morphology}

\subsubsection{Damage Evolution at Weld Metal}

The morphology of the weld metal failure observed in the specimen tested for the longest duration (1778h) among those broken in a Type I manner is shown in Fig. 8. The ultimate failure takes place in a ductile manner, little grain boundary cavitation can be found. Cavity nucleation at non-metallic inclusions, which were identified as oxides from peaks of $\mathrm{Si}$ and $\mathrm{Mn}$ in the EDX spectrum, was not found, either. In the case of the service-exposed seam weld for steam piping in Gallatin Unit 2, where $75 \%$ through wall cracking at weld metal was found after $184000 \mathrm{~h}$ of operation at $566^{\circ} \mathrm{C}$, preferential cavitation at non-metallic inclusions was observed by Lundin et al. ${ }^{8)}$ The seam weld was fabricated by Submerged Arc Weld (SAW) using an acid flux and subcritically heat treated. Creep damage was located at the region adjacent to the fusion boundary and the cause of concentrated attack was ascribed to densely aligned oxide particles entrained from the acid flux. The reason for difference in coherency of oxides between the cracked seam weld and the present work is unknown. However, the dispersed feature and low density of oxide particles in the present weld metal suggest that they would not be of particular importance in the creep damage development.

Although Type I failure in the current work has not been associated with grain boundary cavities, brittle intergranular failure which is typically observed at the HAZ, would be the case due to decrease in ductility of weld metal. Wagner et al. ${ }^{9)}$ found the decreases in rupture ductility of $2.25 \mathrm{Cr}-1 \mathrm{Mo}$ weld metal associated with increase in testing hours. Reduction of Area in weld metal, fabricated with a SMAW technique and then subcritically heat treated, grew lower with testing time and values that were lower than $20 \%$ were obtained.

In the work by Watanabe et $a .^{6)}$ discussed previously, they succeeded in generating the cavitational damage at the PAGB of bainitic microstructure in the weld metal, where recrystallization due to subsequent weld bead depositions took place, by the tests that were longer than $70000 \mathrm{~h}$. They examined the features of weld metal failures tested at $550^{\circ} \mathrm{C}$ and found the change of fracture mode. As with the

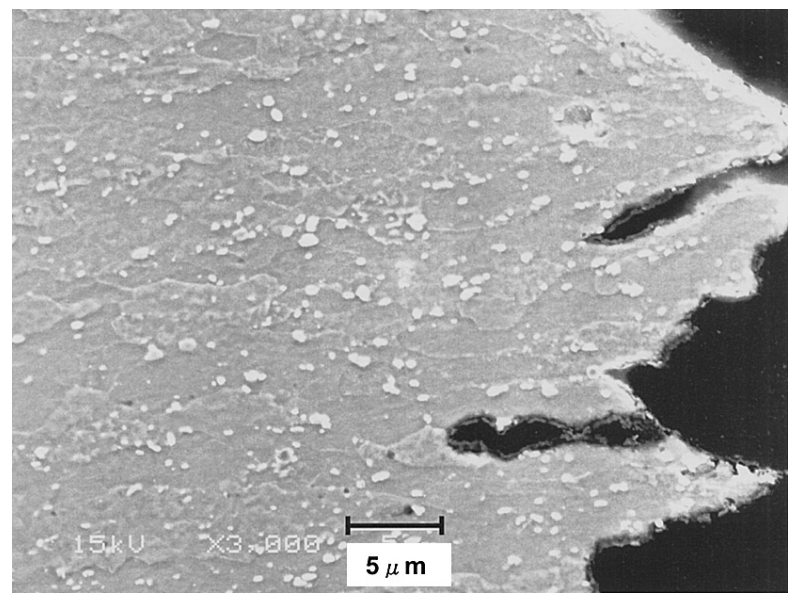

Fig. 8. Feature of transgranular failure at weld metal, tested at $625^{\circ} \mathrm{C}$ and $50 \mathrm{MPa}$ for $1778 \mathrm{~h}$.

present work, transgranular failure took place in the short term tests, which were less than $3000 \mathrm{~h}$. By decreasing testing stresses, however, creep cavitation at PAGB was generated. They speculated that further decrease in stress and temperature would result in the ultimate failure at PAGB. It is noteworthy that the identical phenomenon, preferential creep damage at the grain boundaries of refined grains by multiple heat inputs during welding, has been found in the center of longitudinal seam welds for steam piping in actual plants. $^{10)}$

\subsubsection{Damage Evolution at HAZ}

The grain boundary damage both at the ICZ and the Coarse Grained HAZ (CGZ) was found only on the high residual side. As for the cracking at the CGZ, it did not lead to the ultimate failure. One possible interpretation of higher susceptibility to Type IV and Type III damage in the high residual cast should be the grain boundary embrittlement due to segregation of impurities. Yamauchi et al. ${ }^{11,12)}$ compared creep properties of service-exposed $2.25 \mathrm{Cr}-1 \mathrm{Mo}$ steel containing a higher amount of impurities such as $\mathrm{P}, \mathrm{S}$, $\mathrm{Cu}, \mathrm{As}, \mathrm{Sn}$ and $\mathrm{Sb}$ with those of a new one with lower impurities. Lower ductility and higher creep rate were observed in the service-exposed material in the experiments using the simulated Fine Grained HAZ specimens. 


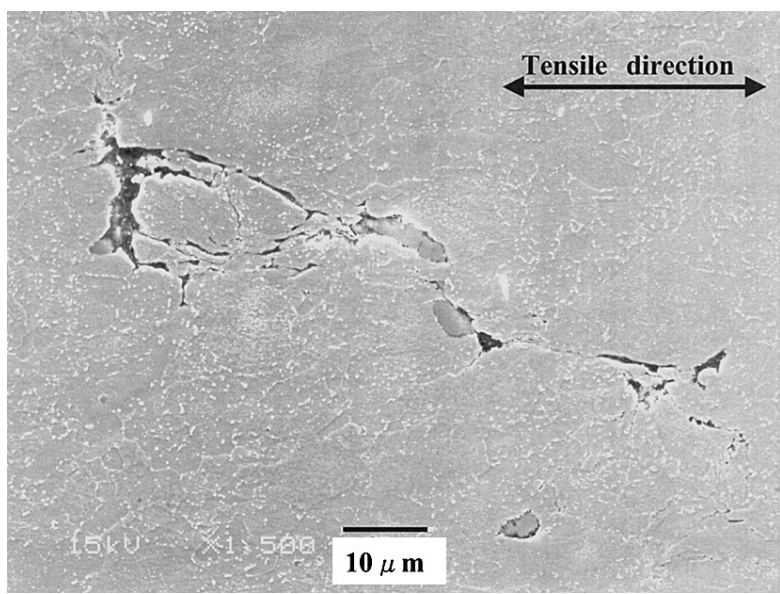

Fig. 9. Creep damage at the unbroken ICZ, tested at $575^{\circ} \mathrm{C}$ and $100 \mathrm{MPa}$ for $1671 \mathrm{~h}$.

Fujibayashi et al. ${ }^{13)}$ found the difference in the sensitivity to Type IV cracking in the service-exposed $1.25 \mathrm{Cr}-0.5 \mathrm{Mo}$ weldment, which was composed of a forged flange and normalized and tempered plate. Although parent material on the flange side containing a higher amount of tramp elements showed higher creep strength, Type IV failure took place only on the flange side. The significant enrichment of $\mathrm{Sb}$ and $\mathrm{Sn}$ on the grain boundaries located at the flange ICZ was found by Auger Electron Spectroscopy in an interrupted crept specimen.

The observation of grain boundary damage at the interruption was made using square cross-weld specimens. However, satisfactory data correlating the life fraction consumed with an extent of cavitation was not derived because of dormant evolution of grain boundary damage till the final stage of failure. In Fig. 9, Type IV damage observed on the opposite side of the rupture for the failed high residual/high residual square specimen is shown. Although the life consumption in the unbroken region can be considered almost unity, grain boundary damage is quite localized. Localized cracking and absence of cavities in the surrounding region suggests that the final failure was caused by linkage of cracks rather than coalescence of grain boundary cavities. And cracks at the grain boundaries, which are inclined and almost parallel to the principal stress, reveal that the grain boundary sliding plays a major role in crack formation. Volumetric growth of grain boundary damage due to opening of the cracking can be seen at the grain boundary that is perpendicular to tensile direction. Under the current testing conditions, where the longest testing duration for weldment is $2066 \mathrm{~h}$, the change in cavity area ratio should be more representative of the remnant life in comparison with the increase in number of cavities.

\subsection{Carbides Morphology}

The morphology of carbides prior to the test found in the parent material of a high residual cast is shown in Fig. 10. The microstructure consists of ferrite containing intragranular needle-like $\mathrm{M}_{2} \mathrm{C}$ and bainite associated with coarse carbides. Due to longer holding time for PWHT than normal practice ( $2 \mathrm{~h}$ per 1 " of thickness), $\mathrm{M}_{23} \mathrm{C}_{6}$ carbides were found in a bainite region. Carbides morphology in commercial parent prior to the test is shown in Fig. 11. The feature

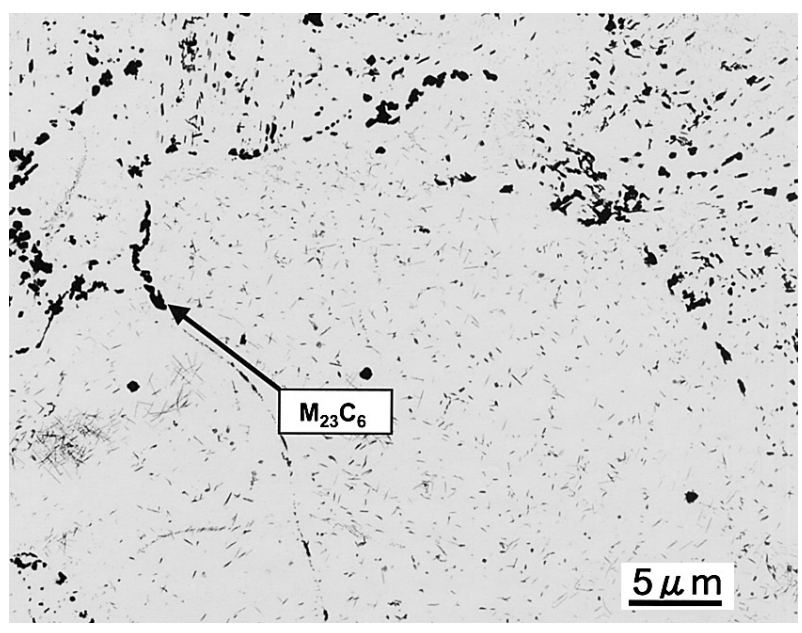

Fig. 10. Carbides morphology of high residual parent prior to the test.

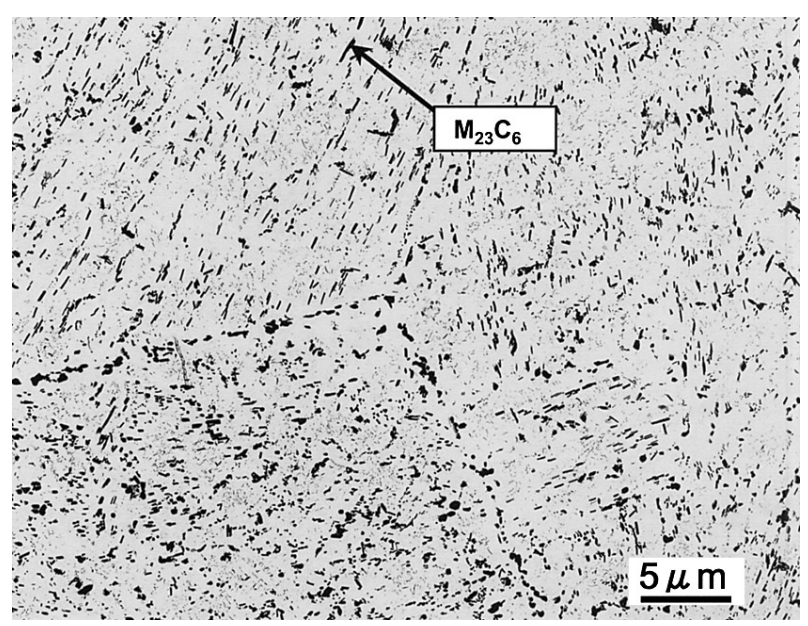

Fig 11. Carbides morphology of commercial parent prior to the test.

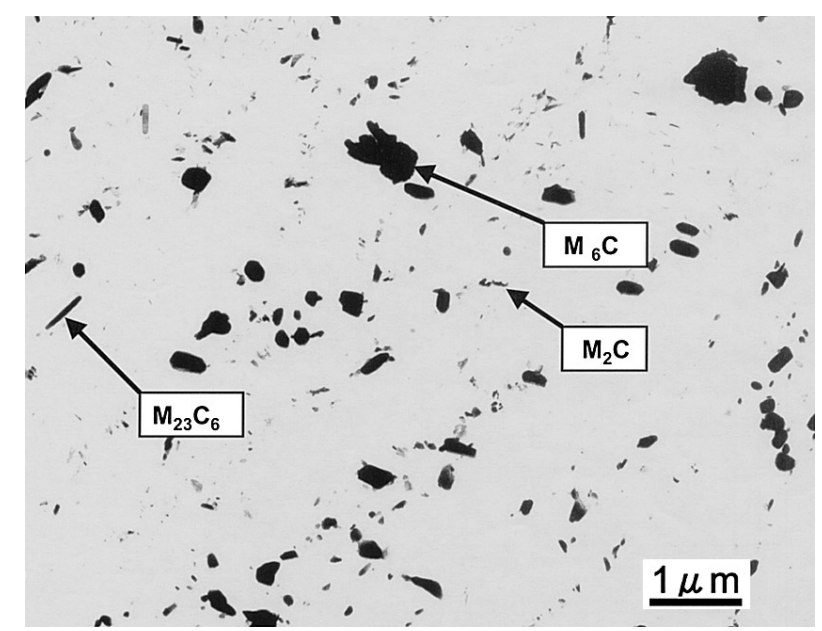

Fig. 12. Carbides morphology of weld metal prior to the test.

of carbide is rather uniform and $\mathrm{M}_{23} \mathrm{C}_{6}$ were found both inside the grains and grain boundaries. $\mathrm{M}_{2} \mathrm{C}$, which were much smaller than those found in high residual parent, were found around rod-like $\mathrm{M}_{23} \mathrm{C}_{6}$. In Fig. 12, carbides in weld metal found before the test are shown. Coarse carbides, shaped ellipsoidal or polygonal, and smaller ones around 
them are observable. It was considered from the electron diffraction pattern that most of these small carbides were $\mathrm{M}_{2} \mathrm{C}$. In weld metal, $\mathrm{M}_{6} \mathrm{C}$ was already generated before the test.

Carbides in high residual parent of the interrupted commercial/high residual welds, crept at $625^{\circ} \mathrm{C}$ and $60 \mathrm{MPa}$, are shown in Fig. 13. The interruption was made after $728 \mathrm{~h}$ of testing. Larson-Miller Parameter $(C=20)$ at the interruption is $20.53 \times 10^{3}$ which gives the equivalent operating time of $178800 \mathrm{~h}$ at $540^{\circ} \mathrm{C}$. Although coarsening and spherodizing of carbides in bainite and resultant generation of Precipitate Free Zone (PFZ) are observed, needle-like carbides in ferrite have increased their density at the core of grains. In a bainite region, $\mathrm{M}_{6} \mathrm{C}$ was detected by electron diffraction pattern.

In the crept commercial parent, appreciable change in carbide spacing was not observed though decreasing in small $\mathrm{M}_{2} \mathrm{C}$ and coarsening of some carbides were progressing. In the case of the crept weld metal, most of small $\mathrm{M}_{2} \mathrm{C}$ are depleted as shown in Fig. 14. And the growth of coarse carbides at the expense of $\mathrm{M}_{2} \mathrm{C}$ is observed.

\section{Discussion}

It is generally accepted that the high temperature ferritic

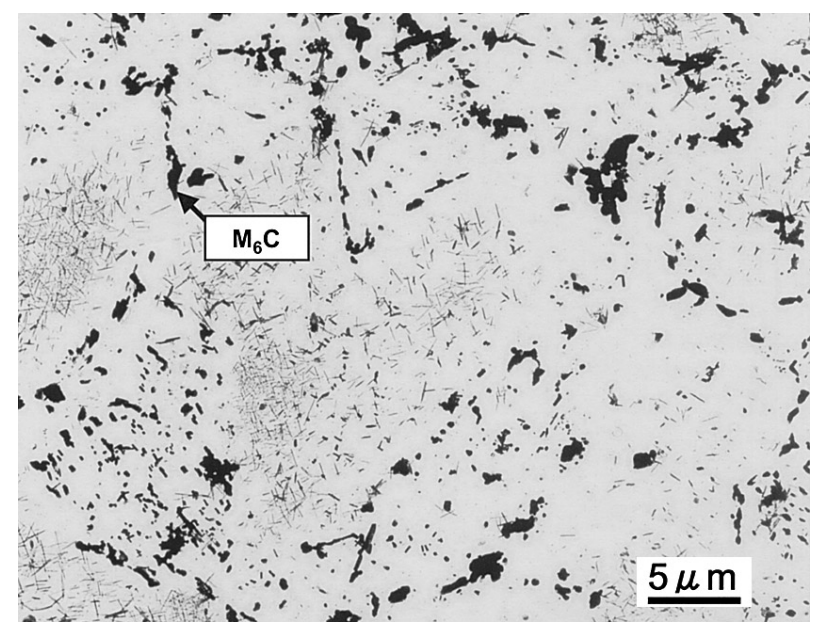

Fig. 13. Carbides morphology of crept high residual parent, tested at $625^{\circ} \mathrm{C}$ and $60 \mathrm{MPa}$ for $728 \mathrm{~h}$. components eventually fail in a Type IV manner when operating duration becomes long. In the present work, however, it was Type I failure which was the most predominant mode in a high $L M P$ region. Testing results suggest the possibility of Type I failures at low stresses that are expected in the actual components. Poor creep strength of weld metal fabricated with a SMAW technique at low stresses are also found in the previous works by Wagner et al. ${ }^{9)}$ and Leyda et $a l{ }^{14)}$ Creep rupture data for weld metal and weldment are shown together with those in the present work in Fig. 15. As for rupture data of weldments, only the results of weld metal failure are plotted. Klueh et al. ${ }^{15)}$ found that creep strength of weld metal depended upon its carbon content. In their experiments conducted at rather high stresses, $103 \mathrm{MPa}$ at the lowest, creep strength in terms of time to rupture and the minimum creep rate increased with carbon content. To show the effect of carbon, data in Fig. 15 were divided into three groups which were low carbon $(\mathrm{C}<0.05 \mathrm{wt} \%)$, medium carbon $(0.05 \mathrm{wt} \% \leq \mathrm{C} \leq 0.1 \mathrm{wt} \%)$ and high carbon $(\mathrm{C}>0.1 \mathrm{wt} \%)$. All the weld metals and welds were given PWHT at the temperatures ranging from 691 to $732^{\circ} \mathrm{C}$. $L M P$-stress plotting shows significant scatter especially at high stresses and no obvious relationship between carbon content and creep strength can be found. At the stress of $60 \mathrm{MPa}$ and lower, all the data lie below the

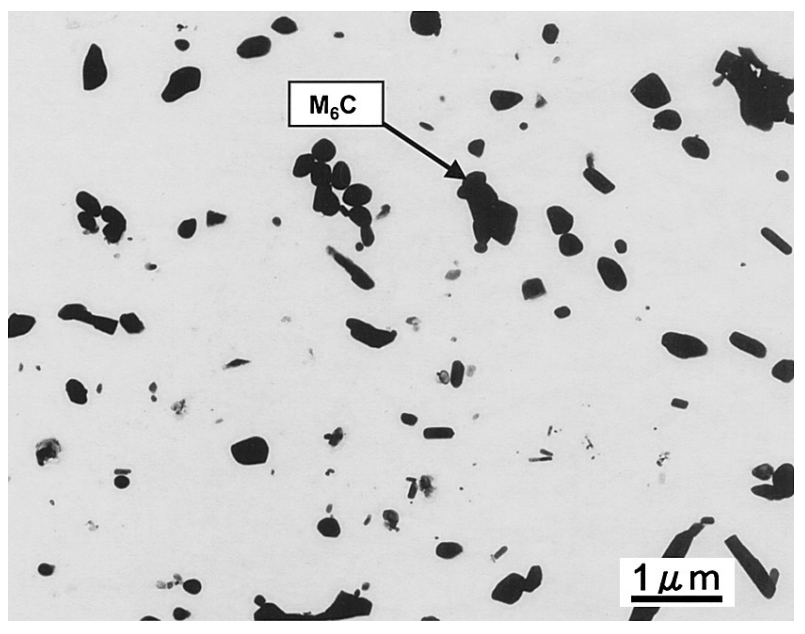

Fig. 14. Carbides morphology of crept weld metal, tested at $625^{\circ} \mathrm{C}$ and $60 \mathrm{MPa}$ for $728 \mathrm{~h}$.

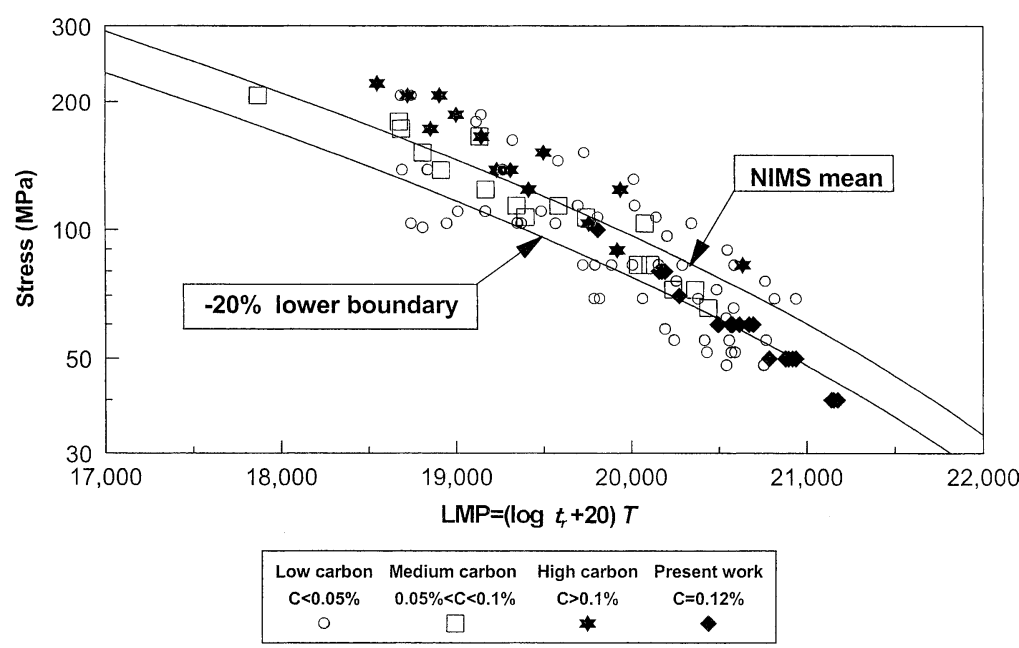

Fig. 15. Creep strength of $2.25 \mathrm{Cr}-1 \mathrm{Mo}$ weld metal fabricated with a SMAW technique. 


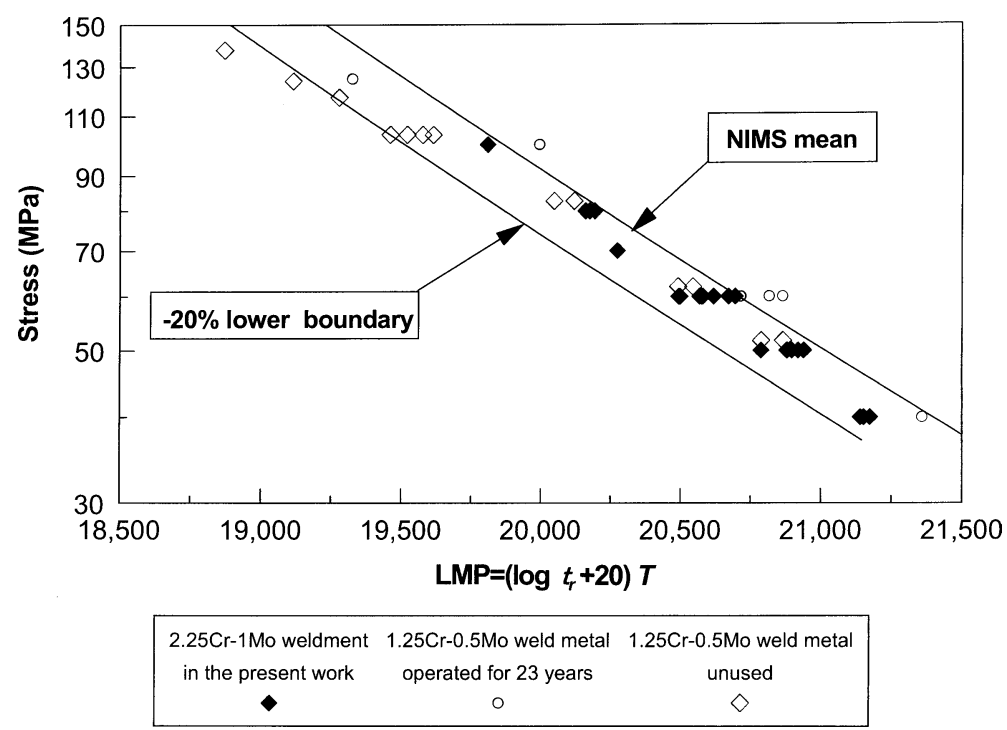

Fig. 16. Comparison of creep strength of $2.25 \mathrm{Cr}-1 \mathrm{Mo}$ weld metal with that of $1.25 \mathrm{Cr}-0.5 \mathrm{Mo}$ weld metal.

lower boundary of base metal independently of the carbon level in weld metal.

It must be noted that Wagner et al. ${ }^{9)}$ and Leyda et al. ${ }^{14)}$ also examined creep properties of $2.25 \mathrm{Cr}-1 \mathrm{Mo}$ steel fabricated using other welding techniques, which were Electroslag and Submerged Arc weld, and they found no significant difference in creep properties associated with welding techniques.

As discussed in Sec. 3.4, carbides in weld metal more readily transform into equilibrium ones in comparison with base metal. The reason for progressive carbide evolution at the weld metal should be attributable to rapid cooling at welding and resultant fully bainitic microstructure containing little proeutectoid and acicular ferrite. In Fig. 16, LMPstress correlation for weld metal fabricated from $1.25 \mathrm{Cr}-0.5 \mathrm{Mo}$ steel with a SMAW technique is plotted together with the present data for $2.25 \mathrm{Cr}-1 \mathrm{Mo}$ steel weldment. For the comparison, mean strength and lower boundary for normalized and tempered plates derived from NIMS data sheet ${ }^{16}$ for normalized and tempered $1.25 \mathrm{Cr}-0.5 \mathrm{Mo}$ steel plates are also shown. The $1.25 \mathrm{Cr}-0.5 \mathrm{Mo}$ steel weld metal in this graph are unused one examined by Leyda et al. ${ }^{14)}$ and the service-exposed examined by Fujibayashi et $a l .{ }^{13)}$ The service exposed weld metal had been in service for twenty-three years at approximately $500^{\circ} \mathrm{C}$. Both welds were subcritically heat treated after multi-run welding. Carbon content for virgin and ex-service weld metal was $0.02 \mathrm{wt} \%$ and $0.066 \mathrm{wt} \%$ respectively. Creep strength of both weld metal are comparable not only to their base metal but also to the weld metal fabricated from $2.25 \mathrm{Cr}-1 \mathrm{Mo}$ steel. From the results shown in Fig. 16, apparent advantage of employing a $2.25 \mathrm{Cr}-1 \mathrm{Mo}$ steel weld consumable over a lower alloying consumable, in terms of creep strength, cannot be found. The microstructure of weld metal of the service-exposed $1.25 \mathrm{Cr}-0.5 \mathrm{Mo}$ steel, observed in the middle of wall-thickness is shown in Fig. 17. Unlike the weld metal fabricated from $2.25 \mathrm{Cr}-1 \mathrm{Mo}$ steel shown in Fig. 3, that for $1.25 \mathrm{Cr}-0.5 \mathrm{Mo}$ steel shows more columnar feature and has retained a higher amount of ferrite. Large difference in a ferrite content in weld deposit can be explained by the work of Evans et al. ${ }^{17)}$ They found that the microstruc-

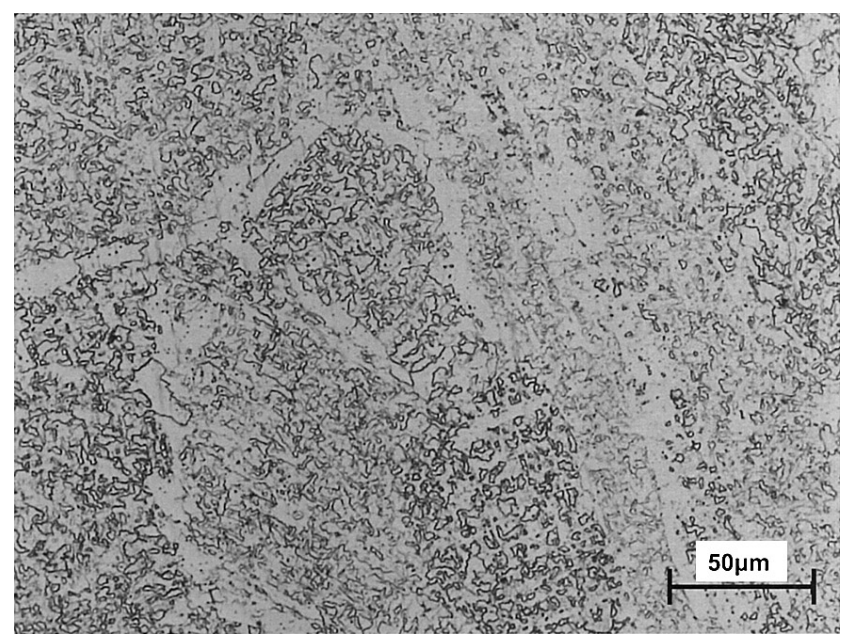

Fig. 17. Microstructure of the service-exposed $1.25 \mathrm{Cr}-0.5 \mathrm{Mo}$ weld metal, operated at $500^{\circ} \mathrm{C}$ for twenty-three years.

ture of weld metal generated in Cr-Mo steels became a function of chromium and molybdenum content. The amount of proeutectoid ferrite decreased with increase in concentration of both elements and that of acicular ferrite peaked when $\mathrm{Cr}$ and $\mathrm{Mo}$ content was approximately $1 \%$ and $0.5 \%$ respectively.

It has been pointed out that the way of sequential transformation of carbides depends upon the original microstructure in which carbides are existing. Yukitoshi et $a l{ }^{18)}$ examined the influence of original microstructures of $2.25 \mathrm{Cr}-1 \mathrm{Mo}$ steel upon creep properties and change in carbide morphology during high temperature exposure. The material was given three types of heat treatment prior to tests, which were Water Quenched (WQ), Oil Quenched (OQ) and Furnace Cooled (FC). The microstructures of a WQ steel was martensite and that for a OQ was bainite plus a small amount of martensite. Equiaxed ferrite and pearlite were generated in a FC steel. As expected, the order of hardness of weld metal was WQ, OQ and FC. However, creep strength of a OQ steel was the highest at high stresses and that of a FC steel became the highest at $60 \mathrm{MPa}$ and lower. They attributed to the reverse of creep strength to the 
stability of needle-like $\mathrm{M}_{2} \mathrm{C}$. Significant difference in remained $\mathrm{M}_{2} \mathrm{C}$ was observed among the three. $\mathrm{M}_{2} \mathrm{C}$ existing in a WQ and OQ steel was depleted when $\operatorname{LMP}(C=20)$ exceeded $21 \times 10^{3}$. On the other hand, $\mathrm{M}_{2} \mathrm{C}$ in a $\mathrm{FC}$ steel had survived until $22 \times 10^{3}$ of $L M P$. In the case of parent material, a commercial cast containing a higher amount of bainite showed higher creep strength than a high residual cast. Therefore, the ideal content of bainite conferring the best creep properties to $2.25 \mathrm{Cr}-1 \mathrm{Mo}$ steel might exist.

\section{Summary}

From the experimental works on $2.25 \mathrm{Cr}-1 \mathrm{Mo}$ steel weldment, following observations and conclusions were made.

(1) As with Type IV cracking, Type I failure of $2.25 \mathrm{Cr}-$ $1 \mathrm{Mo}$ steel welds could be a serious threat to actual components operated at low stresses, independently of carbon content and welding techniques.

(2) Carbides evolution at the weld metal fabricated from $2.25 \mathrm{Cr}-1 \mathrm{Mo}$ steel was more progressive than parent material. A major contributor to creep strength, $\mathrm{M}_{2} \mathrm{C}$, was readily depleted in weld metal, resulting in poor creep resistance.

(3) Low creep strength of $2.25 \mathrm{Cr}-1 \mathrm{Mo}$ weld metal should be ascribed to fully bainitic microstructure in which carbides evolution can be accelerated.

(4) It was suggested that tramp elements, such as P, As, $\mathrm{Sn}$ and $\underline{\mathrm{Sb}}$ could promote grain boundary damage at the ICZ from the higher susceptibility to Type IV cracking of a doped material.

(5) In the present work, in which relatively short term creep tests ( $2066 \mathrm{~h}$ at the longest) were conducted, Type IV damage appeared late in life. And it was associated with volumetric growth of the cavities at the grain boundaries that were perpendicular to stress direction rather than apparent increase in cavity density.

(6) Time to rupture, both for Type IV and Type I fail- ure, was well expressed by the power law relationship.

\section{Acknowledgement}

The authors wish to appreciate New Energy and Industrial Technology Development Organization (NEDO) and Petroleum Energy Center (PEC) for financial support.

\section{REFERENCES}

1) H. J. Shuller, L. Hagn and A. Woitscheck: Maschinenshaden, 1 (1974), 1.

2) A. T. Price and J. A. Wiliams: Recent Advances in Creep and Fracture of Engineering Materials, Pineridge Press, Swansea, (1982), 265.

3) J. F. Langaster: Metallurgy of Welding, 6th Ed., Abington Publishing, Cambridge, (1999), 219

4) NRIM Creep Data Sheet, No. 11B, NIMS, Tsukuba, (1997).

5) D. A. C. Nicol and J. A. Williams: Res. Mech., 14 (1985), 197.

6) T. Watanabe, M. Yamazaki, H. Hongo, J. Kinugawa, T. Tanabe and Y. Momma: J. Soc. Mater. Sci. Jpn., 48 (1999), 122

7) J. F. Henry, F. V. Ellis and C. D. Lundin: WRC Bulletin 354, Welding Research Council, New York, (1990), 39.

8) C. D. Lundin, K. K. Khan, D. Yang, S. Hilton and W. Zielke: WRC Bulletin 354, Welding Research Council, New York, (1990), 1.

9) Properties of Steel Weldments for Elevated Temperature Pressure Containment Applications, ASME, New York, (1978), 103.

10) F. V. Ellis and R. Viswanathan: ASME PVP, 380, ASME, New York, (1998), 59.

11) M. Yamauchi, N. Nishimura, F. Masuyama and T. Sakurai: Proc. of 33rd Symp. on Strength of Materials at High Temperatures, The Society of Materials Science, Kyoto, (1995), 61.

12) M. Yamauchi, N. Nishimura, F. Masuyama and M. Sugazawa: Proc. of 33rd Symp. on Strength of Materials at High Temperatures, The Society of Materials Science, Kyoto, (1995), 65.

13) S. Fujibayashi and T. Endo: ISIJ Int., 42 (2002), 1309.

14) Properties of Steel Weldments for Elevated Temperature Pressure Containment Applications, ASME, New York, (1978), 183.

15) R. J. Klueh and D. A. Canonico: Weld. J., 55 (1976), 381.

16) NRIM Creep Data Sheet, No. 21B, NIMS, Tsukuba, (1994).

17) G. M. Evans and N. Bailey: Metallurgy of Basic Weld Metal, Abington Publishing, Cambridge, (1997), 161

18) T. Yukitoshi and K. Nishida: Tetsu-to-Hagané, 59 (1973), 47. 